\title{
Ouabain Induces Apoptotic Cell Death Through Caspase- and Mitochondria-dependent Pathways in Human Osteosarcoma U-2 OS Cells
}

\author{
WEN-HSIANG CHOU ${ }^{1,2,3}$, KO-LIN LIU ${ }^{4}$, YUNG-LUEN SHIH ${ }^{4,5}$, YING-YING CHUANG ${ }^{6}$, JASON CHOU ${ }^{7}$, \\ HSU-FENG LU ${ }^{6,8}$, HERNG-WOEI JAIR ${ }^{6}$, MING-ZHE LEE ${ }^{6}$, MAN-KUAN AU ${ }^{2 *}$ and JING-GUNG CHUNG ${ }^{9}, 10^{*}$ \\ ${ }^{1}$ School of Medicine, National Defense Medical Center, Taipei, Taiwan, R.O.C.; \\ ${ }^{2}$ Department of Orthopedics, Cheng Hsin General Hospital, Taipei, Taiwan, R.O.C.; \\ ${ }^{3}$ Department of Information Management, St. Mary's Junior College of Medicine, \\ Nursing and Management, Yilan, Taiwan, R.O.C.; \\ ${ }^{4}$ Department of Pathology and Laboratory Medicine, \\ Shin Kong Wu Ho-Su Memorial Hospital, Taipei, Taiwan, R.O.C.; \\ ${ }^{5}$ School of Medicine, College of Medicine, Fu-Jen Catholic University, New Taipei City, Taiwan, R.O.C.; \\ ${ }^{6}$ Department of Clinical Pathology, Cheng Hsin General Hospital, Taipei, Taiwan, R.O.C.; \\ ${ }^{7}$ Department of Anatomic Pathology, Cheng Hsin General Hospital, Taipei, Taiwan, R.O.C.; \\ ${ }^{8}$ Department of Restaurant, Hotel and Institutional Management, \\ Fu-Jen Catholic University, New Taipei City, Taiwan, R.O.C.; \\ ${ }^{9}$ Department of Biological Science and Technology, China Medical University, Taichung, Taiwan, R.O.C.; \\ ${ }^{10}$ Department of Biotechnology, Asia University, Taichung, Taiwan, R.O.C.
}

\begin{abstract}
Background/Aim: Ouabain, a plant-derived product/substance with $\mathrm{Na}^{+} / \mathrm{K}^{+}$-ATPase inhibiting properties, has been shown to exert anti-cancer activity on human cancer cells. This is the first study to investigate the effect of ouabain on apoptotic cell death of human osteosarcoma-derived U-2 OS cells. Materials and Methods: Flow cytometry was used to examine cell viability, cell cycle, and reactive oxygen species (ROS), $\mathrm{Ca}^{2+}$, mitochondrial membrane potential $(M M P)$ and caspase activity. Morphological changes were examined by contrast-phase microscopy, while apoptosisassociated protein levels were analyzed by western blot. Results: Ouabain, at concentrations of 5-60 $\mu \mathrm{M}$, significantly decreased the total viable cells and induced cell
\end{abstract}

*These Authors contributed equally to this work.

Correspondence to: Prof. Jing-Gung Chung, Department of Biological Science and Technology, China Medical University, No 91, Hsueh-Shih Road, Taichung, Taiwan, R.O.C. Tel: +886 422053366, ext. 8000, Fax: +886 422053764, e-mail: jgchung@mail.cmu.edu.tw; Dr. Man-Kuan $\mathrm{Au}$, Department of Orthopedics, Cheng-Hsin General Hospital, No.45, Cheng Hsin St., Pai-Tou, Taipei, Taiwan, R.O.C. Tel: +886228264400 , ext. 5850, Fax: +886 228264517, e-mail: ch1835@chgh.org.tw

Key Words: Ouabain, caspase-dependent pathways, mitochondriadependent pathways, apoptosis, human osteosarcoma U-2 OS cells. morphological changes in a time-dependent manner. It also time-dependently decreased $G_{0} / G_{1}$ phase and increased $S$ and $G_{2} / M$ phase in U-2 OS cells. The production of ROS and the levels of MMPs $\left(\Delta \Psi_{m}\right)$ were inhibited, while $\mathrm{Ca}^{2+}$ production in U-2 OS cells was increased. Regarding cell apoptosis, flow cytometry assay revealed increased caspase-3, -8, and -9 activities in U-2 OS cells. Moreover, western blot results showed that ouabain increased the expression of proapoptotic protein Bax and decreased the expression of antiapoptotic protein Bcl-2 in U-2 OS cells. Furthermore, results also showed that ouabain increased cytochrome c release, apoptosis-inducing factor (AIF) and endonuclease (Endo) $G$ that is associated with apoptosis through caspase-dependent and -independent pathway in U-2 OS cells. Conclusion: Our findings provide important insight into the cytotoxic effects of ouabain on U-2 OS cells, in vitro, which are mediated at least partly via cell apoptosis induction.

Osteosarcoma is a type of bone cancer, the most common primary bone malignancy in children and adolescent population (1). According to the Ministry of Health and Welfare, bone cancer mortality rate was 0.4 per 100,000 people in Taiwan, in 2016 (2). Currently, therapeutic approaches for patients with osteosarcoma include a combination of surgery and intensive multi-agent chemotherapy. Chemotherapy for osteosarcoma patients increased the five-year survival rate to $60-75 \%$ (3). 
However, high-dose chemotherapy on patients with osteosarcoma has been shown to exhibit severe side effects, limiting further use of these drugs $(4,5)$. Therefore, it is urgent to reduce the side-effects of chemotherapy on patients with osteosarcoma. Many studies have focused on natural products in order to improve the efficiency of clinical anticancer drugs.

Ouabain, a natural compound derived from Acocanthera ouabaio and Strophanthus gratus, has been used as a therapeutic agent for congestive heart failure, due to its positive ionotropic effect on cardiac muscle $(6,7)$. Ouabain has been reported to promote TRAIL-mediated cancer cell death, via Mcl-1 down-regulation (8). Moreover, inhibition of $\mathrm{Na}^{+} / \mathrm{K}^{+}$-ATPase activity by ouabain led to selective death of drug-resistant $\mathrm{T} 98 \mathrm{G}$ glioblastoma cells and disruption of $\mathrm{K}^{+}$ homeostasis in a time- and concentration-dependent manner (9). Ouabain has also been shown to induce antiproliferative effects on SW13 and H295R adrenocortical tumor cell lines and primary adrenocortical tumor cells (10). Furthermore, ouabain induced apoptotic cell death in HeLa cells via the activation of Rho-associated kinases (Rho/ROCK) pathway, which is differentially regulated in cancer cell lines and normal cells during cell death induction (11).

Numerous studies have shown that ouabain exerts anticancer activities on many human cancer cell lines and also inhibits migration and invasion of cancer cells. However, this is the first study to investigate the effects of ouabain on U-2 OS human osteosarcoma cells and the underlying molecular mechanisms, in vitro. Our results showed that ouabain induced apoptotic cell death via caspases- and mitochondria-dependent pathways.

\section{Materials and Methods}

Chemicals and reagents. Dimethyl sulfoxide (DMSO), propidium iodide (PI), ouabain, L-glutamine and penicillin-streptomycin were purchased from Sigma Chemical Co. (St. Louis, MO, USA). McCoy's $5 \mathrm{~A}$ medium and fetal bovine serum (FBS) were purchased from GIBCO $^{\circledR} /$ Invitrogen Life Technologies (Carlsbad, California, USA).

Cell culture. U-2 OS cell line was purchased from the Food Industry Research and Development Institute (Hsinchu, Taiwan). Cells were cultured in McCoy's 5A medium containing 10\% FBS, 2 mM Lglutamine, and $1 \%$ antibiotics $(100 \mathrm{U} / \mathrm{ml}$ penicillin and $100 \mu \mathrm{g} / \mathrm{ml}$ streptomycin) in a humidified atmosphere of $5 \% \mathrm{CO}_{2}$ at $37^{\circ} \mathrm{C}$, as previously described $(12,13)$.

Cell's morphological changes and viability assays. U-2 OS cells $\left(1.6 \times 10^{5}\right.$ cells/well $)$ were maintained in 12 -well plate with McCoy's $5 \mathrm{~A}$ medium for $24 \mathrm{~h}$ then were treated with $1 \%$ DMSO (control) or ouabain at a final concentration $(5,10,20,40$, and $60 \mu \mathrm{M})$. Cells were treated trypsin for $5 \mathrm{~min}$, and collected by centrifugation at 1500 rpm for $5 \mathrm{~min}$, and stained with PI $(5 \mu \mathrm{g} / \mathrm{ml})$ for total viable cell examination by flow cytometry (BD Biosciences, FACS Calibur, San Jose, CA, USA), as previously described (12). Otherwise, cells were treated with $1 \%$ DMSO (control) or $5 \mu \mathrm{M}$ of ouabain for $0,12,24$ and $48 \mathrm{~h}$ and were examined with contrast-phase microscopy (magnification $\times 400)($ Olympus, Tokyo, Japan) $(12,14)$.

Measurement of cell cycle distribution by flow cytometry. U-2 OS cells $\left(1.6 \times 10^{5}\right.$ cells/well) were treated with $1 \%$ DMSO (control) or $5 \mu \mathrm{M}$ of ouabain for $0,12,24$ and $48 \mathrm{~h}$ and were collected for cell cycle distribution assessment using flow cytometry. Analysis was performed with CellQuest and Mod Fit computer programs (BD Biosciences Clontech, Palo Alto, CA) as described previously (15, 16). The proportions of cells in the $G_{0} / G_{1}, S$, and $G_{2} / M$ phases were represented in DNA histograms.

ROS, intracellular $\mathrm{Ca}^{2+}$, and $M M P\left(\Delta \Psi_{m}\right)$ assays by flow cytometry. U-2 OS cells $\left(1.6 \times 10^{5}\right.$ cells/well $)$ were treated with $1 \%$ DMSO (control) or $5 \mu \mathrm{M}$ of ouabain for $0,12,24$ and $48 \mathrm{~h}$. Cells were harvested, centrifuged, and resuspended in $500 \mu \mathrm{l}$ of dihydrodichlorofluorescein diacetate $\left(\mathrm{H}_{2} \mathrm{DCF}-\mathrm{DA}, 10 \mu \mathrm{M}\right), 3,3^{\prime}$ dihexyloxacarbocyanine iodide $\left(\mathrm{DiOC}_{6}, 4 \mu \mathrm{M}\right)$, or fluo-3 acetoxymethyl ester (Fluo-3/AM, $2.5 \mu \mathrm{g} / \mathrm{ml}$ ) for $30 \mathrm{~min}$, for the measurement of $\operatorname{ROS}\left(\mathrm{H}_{2} \mathrm{O}_{2}\right), \Delta \Psi_{\mathrm{m}}$, levels or intracellular $\mathrm{Ca}^{2+}$, respectively, using flow cytometry as previously described $(12,17)$.

Measurements of caspase-3, caspase-8, and caspase-9 activities. Activity of caspases was measured by flow cytometry using commercially available fluorescent caspase substrates (OncoImmunin, Inc., Gaithersburg, MD, USA). Initially, U-2 OS cells $\left(1.6 \times 10^{5}\right.$ cells/well) were treated with $1 \%$ DMSO (control) or $5 \mu \mathrm{M}$ of ouabain for $0,12,24$ and $48 \mathrm{~h}$. Cells were harvested, centrifuged and then were resuspended in $25 \mu \mathrm{l}$ of $10 \mu \mathrm{M}$ substrate solution CaspaLux8L1D2 (for caspase-8), PhiPhiLux-G1D1 (for caspase-3), or CaspaLux9-M1D2 (for caspase-9) and were incubated at $37^{\circ} \mathrm{C}$ for $60 \mathrm{~min}$. Cells were assayed as described previously $(12,18)$.

Western blot analysis. U-2 OS cells $\left(2.4 \times 10^{6}\right.$ cells $)$ were treated with $1 \%$ DMSO (control) or $5 \mu \mathrm{M}$ of ouabain for $0,12,24$ and $48 \mathrm{~h}$ and were collected and resuspended in lysis buffer [ $40 \mathrm{mM}$ Tris$\mathrm{HCl}$ (pH 7.4), $10 \mathrm{mM}$ EDTA, $120 \mathrm{mM} \mathrm{NaCl}, 1 \mathrm{mM}$ dithiothreitol, $0.1 \%$ Nonide P-40] for measuring total protein as described previously (12). An equal amount of total protein $(30 \mu \mathrm{g})$ was separated by polyacrylamide gel electrophoresis and was transferred onto polyvinylidene difluoride (PVDF) membranes (EMD Millipore, Bedford, MA, USA). After washed, blots were incubated with primary antibodies. The primary antibodies used were: antiendonuclease G (Endo G), anti-apoptosis-inducing factor (AIF), anticytochrome c, anti-growth arrest- and DNA damage-inducible gene 153 (GADD153), anti-activating transcription factor 6 $\alpha$ (ATF6 $\alpha$ ), anti-glucose-regulated protein (GRP78) and anti-calpain 1 (Santa Cruz Biotechnology, Santa Cruz, CA, USA), anti-B-cell lymphoma 2 (Bcl-2), anti-Bax, anti-poly(ADP-ribose) polymerase (PARP), antiapoptotic protease activating factor-1 (Apaf-1) (Cell Signaling, St Louis, MO, USA), anti-superoxide dismutase 1 (SOD1), antisuperoxide dismutase 2 (SOD2), anti-catalase, anti-Fas-associated protein with death domain (FADD), anti-Fas-Ligand (FasL) (Millipore, Temecula, CA, USA), anti-Fas and anti-caspase-4 (BD Biosciences, San Jose, CA, USA) and anti- $\beta$-actin (Sigma-Aldrich, St. Louis, MO, USA). Membranes were stained with the appropriate secondary antibodies (GeneTex, Irvine, CA, USA) and were visualized with enhanced chemiluminescence detection (Millipore, Temecula, CA, USA) as described previously $(12,19)$. ImageJ 1.490 software (National Institutes of Health, Bethesda, MD, USA) was used to quantify changes in protein expression by densitometry 
analysis and using $\beta$-actin as the loading control.

Statistical analysis. All data are expressed as the mean \pm standard deviation (S.D.) from at least 3 experiments. Differences between groups were analyzed by one-way analysis of variance and Dunnett test for multiple comparisons (SigmaPlot for Windows version 12.0; Systat Software, Inc., San Jose, CA). Comparisons were made between groups of ouabain-treated cells and untreated cells (control). Differences with $p<0.05(*), p<0.01(* *)$, and $p<0.001$ $(* * *)$ were considered statistically significant.

\section{Results}

Ouabain induced cell morphological changes and decreased the cell viability of $U-2$ OS cells. U-2 OS cells treated with 5-60 $\mu \mathrm{M}$ ouabain for $24 \mathrm{~h}$ showed a significant reduction of viable cell number [24 h: $5 \mu \mathrm{M}(72.47 \pm 5.67 \%, p<0.001) ; 10$ $\mu \mathrm{M} \quad(65.40 \pm 5.46 \%, p<0.001) ; 20 \mu \mathrm{M} \quad(60.44 \pm 6.23 \%$, $p<0.001) ; \quad 40 \mu \mathrm{M} \quad(57.88 \pm 1.41 \%, p<0.001) ; 60 \mu \mathrm{M}$ $(54.95 \pm 5.69 \%, p<0.001)]$ compared to untreated control cells $(100.00 \pm 0.5 \%)$. The 48 -h group had a lower viable cell number compared to $24-\mathrm{h}$. treated U-2 OS cells [48 h: $5 \mu \mathrm{M}$ (52.53 $\pm 2.15 \%, p<0.001) ; 10 \mu \mathrm{M}(43.02 \pm 4.50 \%, p<0.001)$; $20 \mu \mathrm{M}(38.45 \pm 6.19 \%, p<0.001) ; 40 \mu \mathrm{M}(34.90 \pm 0.56 \%$, $p<0.001) ; 60 \mu \mathrm{M}(34.18 \pm 4.37 \%, p<0.001)]$ compared to untreated control cells $(100.00 \pm 0.85 \%)$ (Figure 1A). Thus, the $5 \mu \mathrm{M}$ concentration ( $\mathrm{IC}_{50}$ ) of ouabain was selected for further cell morphological changes examination and results are presented in Figure 1B. Treatment of U-2 OS cells with ouabain at $5 \mu \mathrm{M}$ significantly induced cell morphological changes and decreased total viable cell number.

Ouabain induced $G_{2} / M$ arrest in U-2 OS cells. Cell cycle distribution results are shown in Figure 2. Results indicated that ouabain induced $\mathrm{G}_{2} / \mathrm{M}$ phase arrest in a time-dependent manner (Figure 2B; 12 h: 1.41-fold, $p=0.002$; 24 h: 2.47 fold, $p<0.001 ; 48 \mathrm{~h}: 3.25$-fold, $p<0.001)$ compared to untreated controls. Also, ouabain was shown to induce subG1 phase (apoptotic cell death) in U-2 OS cells after 12-24 $\mathrm{h}$ treatment (Figure 2C; $12 \mathrm{~h}: 1.48$-fold, $p=0.618 ; 24 \mathrm{~h}: 3.02-$ fold, $p=0.011 ; 48 \mathrm{~h}$ : 10.43 -fold, $p<0.001)$ compared to untreated controls.

Ouabain affect ROS, intracellular $C a^{2+}$, and $M M P\left(\Delta \Psi_{m}\right)$ levels in $U-2$ OS cells. Treatment of U-2 OS cells with $5 \mu \mathrm{M}$ of ouabain for $0,12,24$ and $48 \mathrm{~h}$ revealed that ouabain decreased ROS production (Figure 3A; $12 \mathrm{~h}$ : 0.34-fold, $p<0.001 ; 24$ h: 0.28 -fold, $p<0.001 ; 48$ h: 0.25 -fold, $p<0.001$ ) and $\Delta \Psi_{\mathrm{m}}$ levels (Figure 3B; $12 \mathrm{~h}$ : 0.67 -fold, $p<0.001 ; 24 \mathrm{~h}$ : 0.59 -fold, $p<0.001 ; 48 \mathrm{~h}: 0.59$-fold, $p<0.001)$, while increased $\mathrm{Ca}^{+2}$ productions (Figure $3 \mathrm{C} ; 12 \mathrm{~h}$ : 1.63 -fold, $p<0.001 ; 24$ h: 1.79-fold, $p<0.001 ; 48$ h: 1.61 -fold, $p<0.001$ ) in U-2 OS cells compared to untreated control cells.
Ouabain increased caspase activity in U-2 OS cells. U-2 OS cells were treated with $5 \mu \mathrm{M}$ for $0,12,24$ and $48 \mathrm{~h}$. Assays of the intracellular activity of caspase $-3,-8$, and -9 showed that ouabain increased the activity of examined caspases. More specifically, ouabain treatment for 24-48 h significantly increased caspase-8 (24 h: 1.29-fold, $p<0.001$; $48 \mathrm{~h}: 1.52$-fold, $p<0.001$ ) and caspase-3 (24 h: 1.42-fold, $p<0.001 ; 48 \mathrm{~h}: 1.50$-fold, $p<0.001)$ activity, though caspase9 activity was significantly increased after $12 \mathrm{~h}$ of ouabain treatment $(12 \mathrm{~h}: 1.43$-fold, $p<0.001 ; 24 \mathrm{~h}: 1.47$-fold, $p<0.001 ; 48 \mathrm{~h}: 1.59$-fold, $p<0.001)$ in U-2 OS cells compared to untreated control cells (Figure 4B).

Ouabain alters levels of proteins associated with apoptotic cell death of $U-2$ OS cells. Western blot analysis revealed that ouabain treatment altered the expression levels of apoptosisassociated proteins in U-2 OS cells in a time-dependent manner (Figure 5). Ouabain significantly increased the levels of proteins associated with estrogen receptor (ER) stress, such as SOD1 (24 h: 1.6-fold, $p<0.05 ; 48$ h: 2.0-fold, $p=0.001$ ), SOD2 (24 h: 1.8-fold, $p<0.01 ; 48$ h: 1.6-fold, $p<0.01$ ) and catalase (24 h: 1.9-fold, $p<0.001 ; 48$ h: 2.0 -fold, $p<0.001$ ) and Calpain 1 (48 h: 1.3-fold, $p<0.001$ ), caspase-4 (48 h: 1.3fold, $p<0.001$ ), GRP 78 (48 h: 1.4-fold, $p=0.001$ ) and GADD153 (48 h: 1.4-fold, $p<0.001$ ). Ouabain effects on apoptosis-related proteins were observed after $12 \mathrm{~h}$ of treatment. Specifically, ouabain increased the expression levels of pro-apoptotic proteins, such as Bax (12 h: 1.9-fold, $p<0.05 ; 24$ h: 2.9-fold, $p=0.001 ; 48$ h: 3.6-fold, $p<0.001)$, AIF (24 h: 5.9-fold, $p<0.001 ; 48$ h: 5.5 -fold, $p<0.001$ ), Endo G (12 h: 2.5-fold, $p<0.001 ; 24$ h: 3.8-fold, $p<0.001 ; 48$ h: 3.6-fold, $p<0.001)$, cytochrome $c$ (24 h: 3.5-fold, $p<0.001$; 48 h: 2.0-fold, $p<0.01$ ), Apaf-1 (12 h: 1.3-fold, $p=0.471 ; 24$ h: 1.8 -fold, $p<0.05 ; 48$ h: 2.4-fold, $p<0.01)$ and PARP (12 h: 2.2-fold, $p<0.001 ; 24$ h: 4.6-fold, $p<0.001 ; 48$ h: 3.7-fold, $p<0.001)$; however, it decreased anti-apoptotic protein Bcl-2 (24 h: 0.3-fold, $p<0.001 ; 48$ h: 0.3-fold, $p<0.001$ ) in U-2 OS cells. Furthermore, ouabain treatment for $24-48 \mathrm{~h}$ increased FADD (24 h: 1.3 -fold, $p<0.01 ; 48$ h: 1.3 -fold, $p<0.01$ ), Fas (24 h: 1.6-fold, $p<0.01 ; 48$ h: 2.0 -fold, $p<0.001$ ), and FasL (24 h: 1.3-fold, $p<0.05 ; 48 \mathrm{~h}: 1.5$-fold, $p<0.01$ ) that are associated with Fas receptor for the induction of cell apoptosis. The protein levels in U-2 OS cells were significantly affected in ouabain-treated cells compared with untreated-cells.

\section{Discussion}

Ouabain has been shown to induce cytotoxic effects in many human cancer cell lines and has also been reported to inhibit migration and invasion of human liver cancer A549 cells (15). However, there is not any report for human bone cancer cells. Herein, we investigated the in vitro cytotoxicity of ouabain 


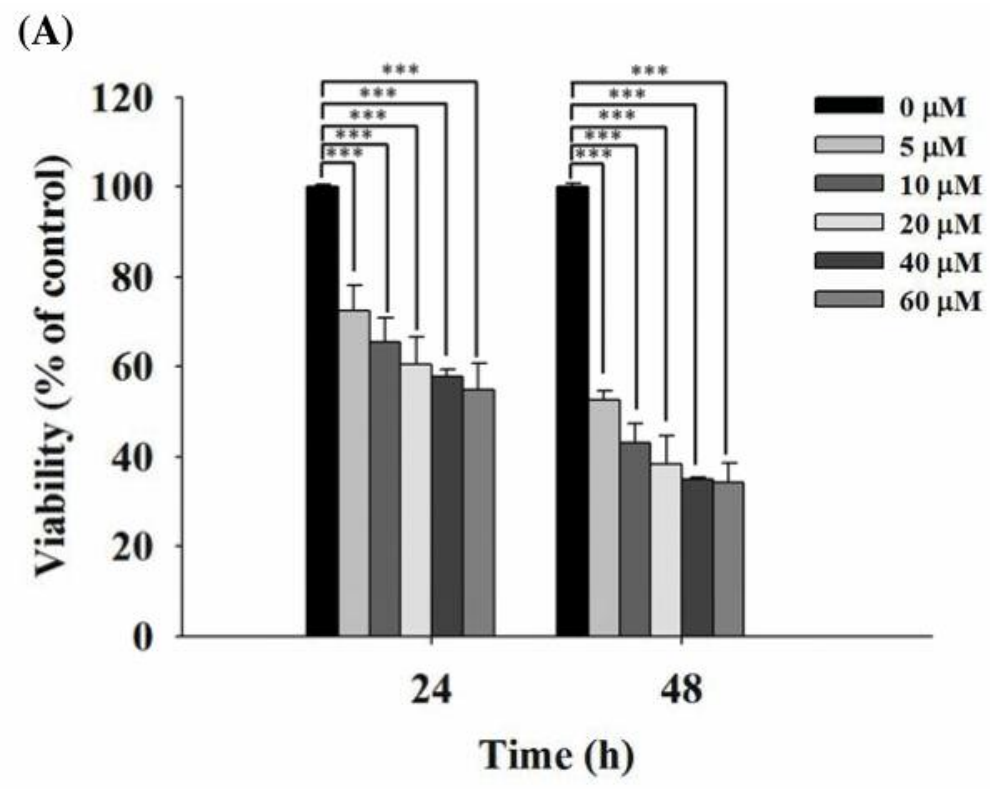

(B)

Control

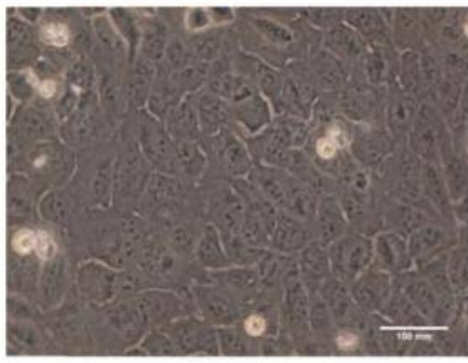

$24 \mathrm{~h}$

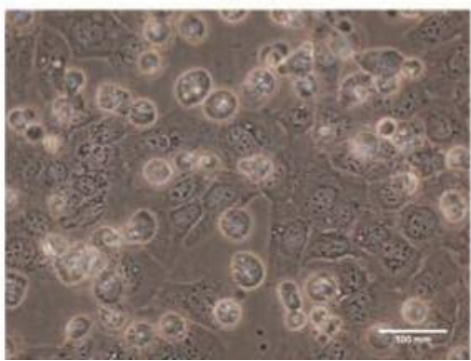

$12 \mathrm{~h}$

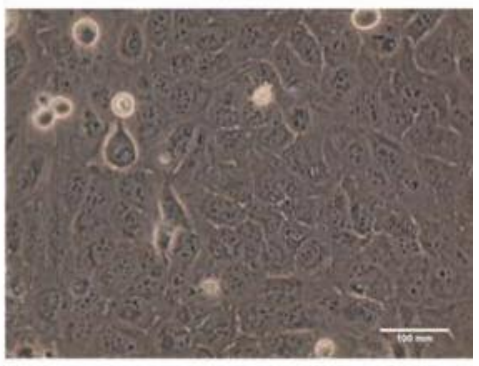

$48 \mathrm{~h}$

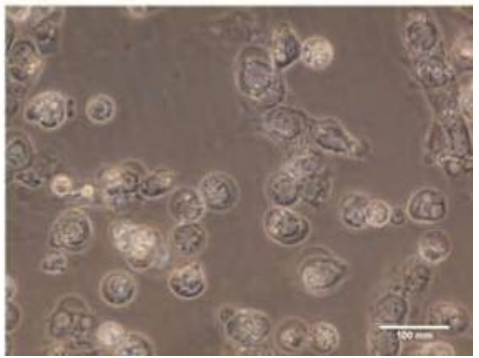

Figure 1. Ouabain affects the morphology and percentage of viable U-2 OS cells. Cells treated with ouabain (0, 5, 10, 20, 40, and 60 $\mu M)$ for 24 and $48 \mathrm{~h}$ were examined by flow cytometry. Bars $(A)$ indicate the percentage of viable cells. Morphological changes of U-2 OS treated with ouabain $(5 \mu M)$ were examined via phase-contrast microscopy at magnification $\times 400(B)$. Asterisks denote the statistical significance of the experimental group compared to the corresponding control group $(* p<0.05, * * p<0.01 * * * p<0.001)$.

on human osteosarcoma-derived U-2 OS cells, focusing on the induction of apoptosis. Results indicated that i) ouabain at concentrations 5-60 $\mu \mathrm{M}$ significantly reduced the total viable cell number and induced cell morphological changes (at a concentration of $5 \mu \mathrm{M}$ ); ii) ouabain decreased $\mathrm{G}_{0} / \mathrm{G}_{1}$ phase and increased $G_{2} / M$ phase and sub- $G_{1}$ phase in cell cycle distribution; iii) ouabain decreased ROS production and the levels of $\Delta \Psi_{\mathrm{m}}$, though increased the production of $\mathrm{Ca}^{2+}$; 
(A)

Control

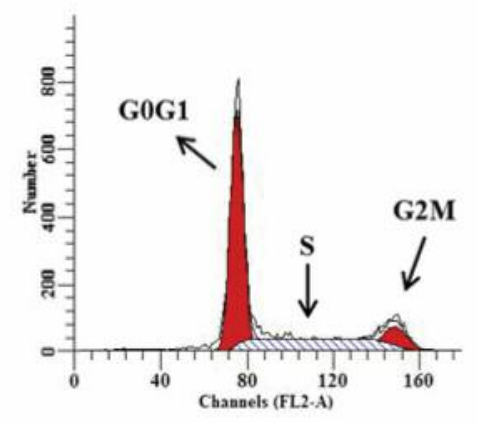

$24 \mathrm{~h}$

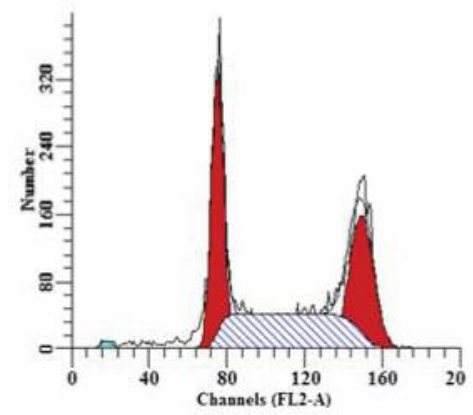

(B)
$12 \mathrm{~h}$

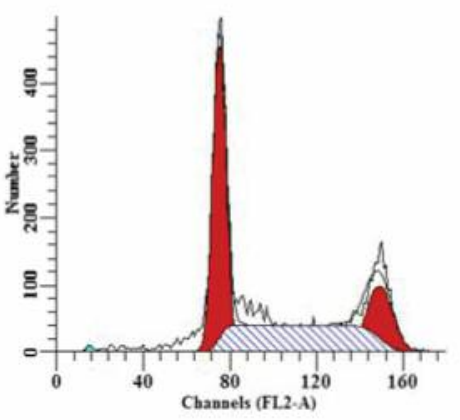

$48 \mathrm{~h}$

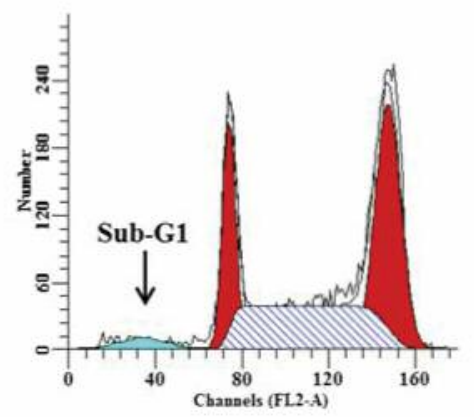

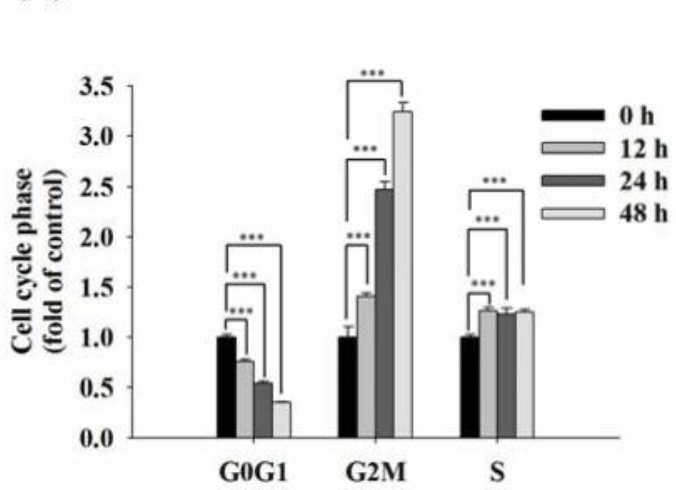

(C)

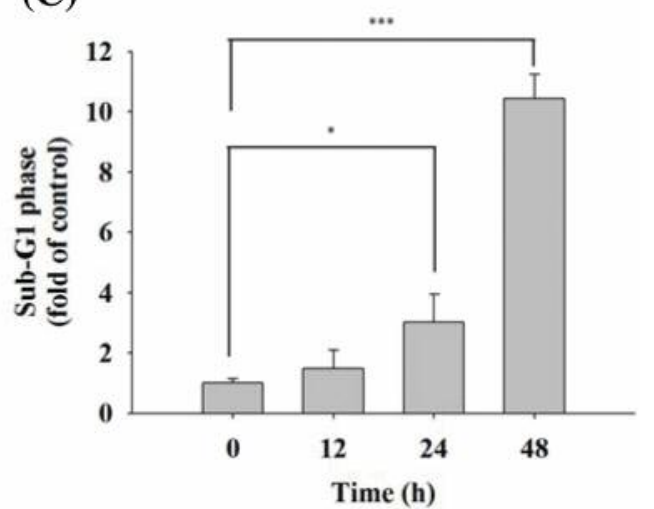

Figure 2. Ouabain affects cell-cycle distribution in U-2 OS cells. Cells were treated with $5 \mu M$ for 0, 12, 24 and 48 h and cell-cycle distribution using flow cytometry. The proportions of cells in the $G_{0} / G_{1}, S$, and $G_{2} / M$ phases were represented in DNA histograms (A). The percentages of cellcycle distribution were measured $(B)$ and sub-G $G_{1}$ phase were quantified $(C)$. Asterisks denote the statistical significance of the experimental group compared to the corresponding control group $(* p<0.05$, **p $<<0.01 * * * p<0.001)$.

iv) ouabain increased caspase-3, -8 and -9 activity; v) ouabain induced apoptosis via the Fas/FasL pathway, as indicated by the protein expression of FADD, Fas, FasL, the increased proapoptotic Bax and decreased anti-apoptotic $\mathrm{Bcl}-2$ protein levels on U-2 OS cells. This is in agreement with previous reports showing that ouabain induced cytotoxic effects on human cancer cell lines $(10,11)$. Thus, concentration of $5 \mu \mathrm{M}$ of ouabain was selected to examine the expression of apoptotic pathway-related proteins in U-2 OS cells.

The present results indicated that ouabain significantly decreased total viable cell number and induced morphological changes on treated U-2 OS cells, in a dose- 


\section{(A)}
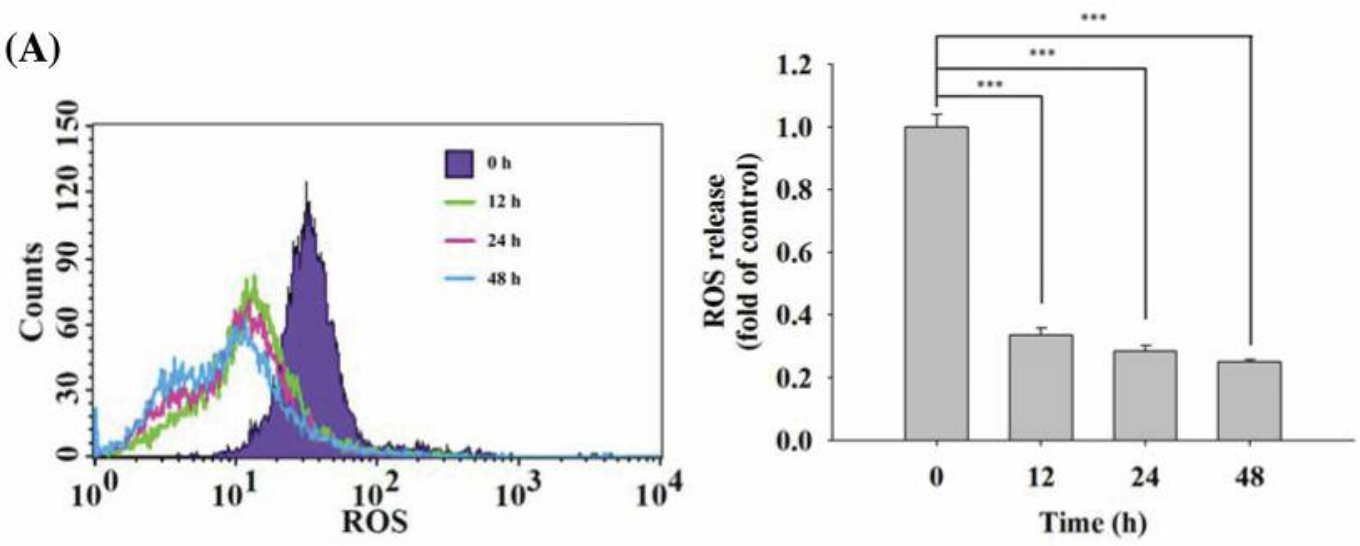

(B)
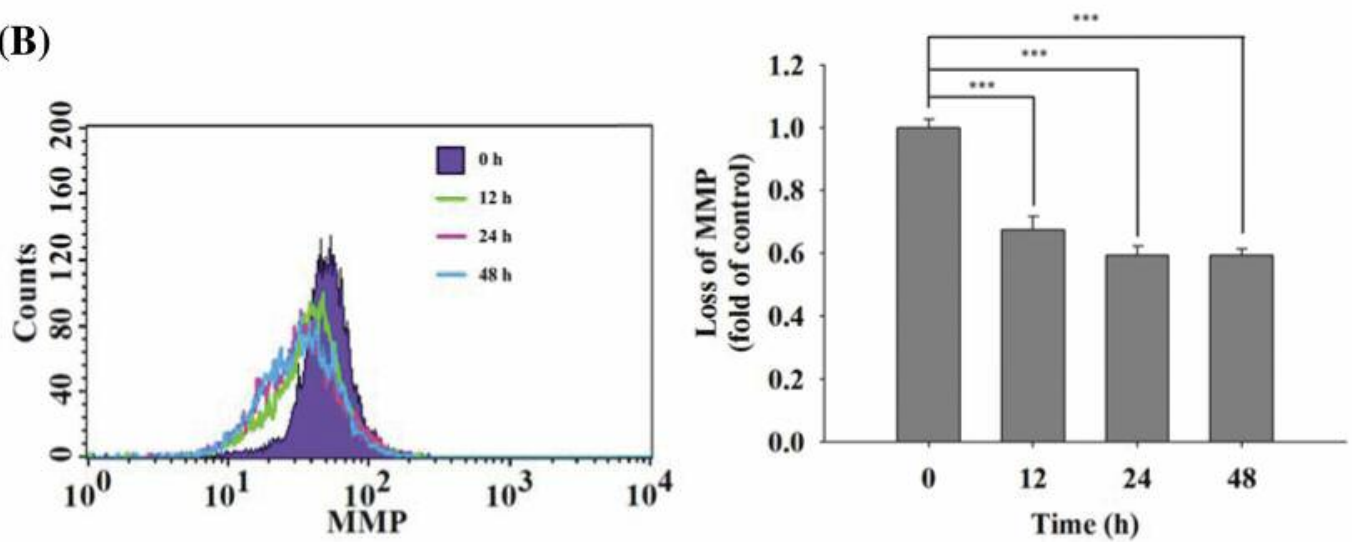

(C)
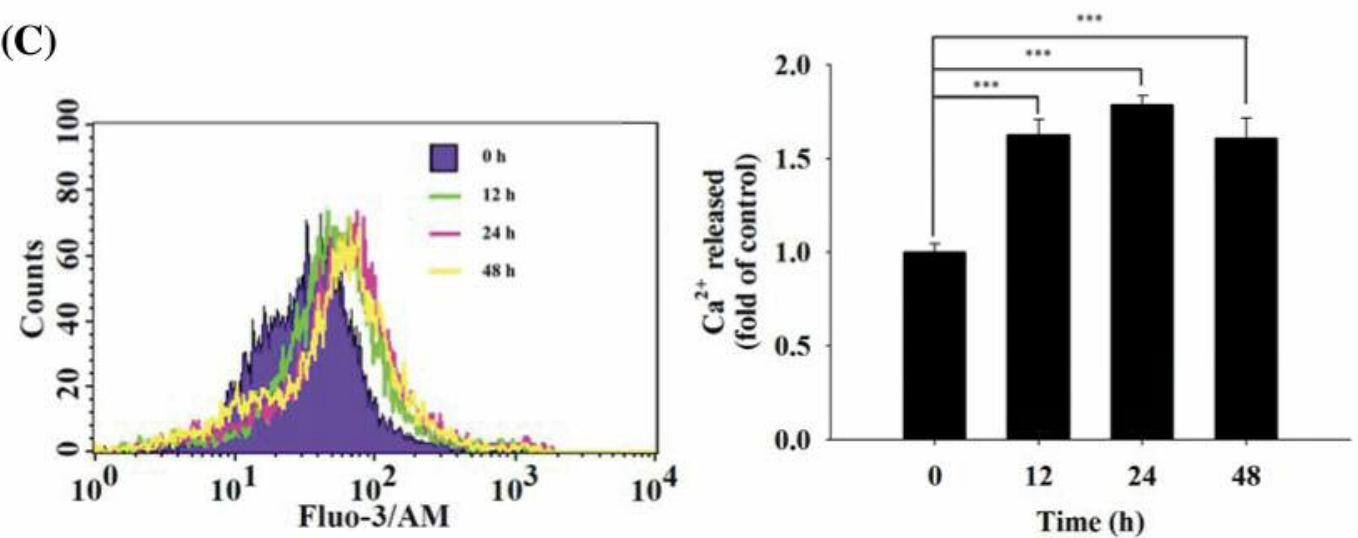

Figure 3. Ouabain affects reactive oxygen species (ROS), intracellular $\mathrm{Ca}^{2+}$ and mitochondrial membrane potential ( $\left.\triangle \Psi_{m}\right)$ in $U-2$ OS. Cells $\left(1.6 \times 10^{5}\right.$ cells/well) were treated with $5 \mu \mathrm{M}$ for $0,12,24$ and $48 \mathrm{~h}$. Ouabain treatment resulted in reduced release of $\mathrm{ROS}_{(\mathrm{H}}\left(\mathrm{H}_{2} \mathrm{O}_{2}\right)(\mathrm{A})$, and of $\Delta \Psi_{\mathrm{m}}$ levels $(B)$, while increased intracellular $\mathrm{Ca}^{2+}$ release $(C)$. Asterisks denote the statistical significance of the experimental group compared to the corresponding control group $(* p<0.05, * * p<0.01, * * * p<0.001)$.

and time-dependent manner, respectively. This finding is in agreement with previous studies $(10,11)$. Results also showed that ouabain significantly decreased $G_{0} / G_{1}$ phase and increased $G_{2} / M$ phase and sub- $G_{1}$ arrest in cell-cycle distribution on U-2 OS cells (Figure 2) and both effects of ouabain are time-dependent. This is in line with other reports that ouabain induced $\mathrm{G}_{2} / \mathrm{M}$ phase arrest and increase $\mathrm{S}$ phase in hepatoma cell lines (HepG2 and SMMC-7721) cancer cells (20). Ouabain inhibits neuroblastoma SH-SY5Y cells in vitro and reducing by $>50 \%$ tumor growth when $\mathrm{SH}$ - 
A
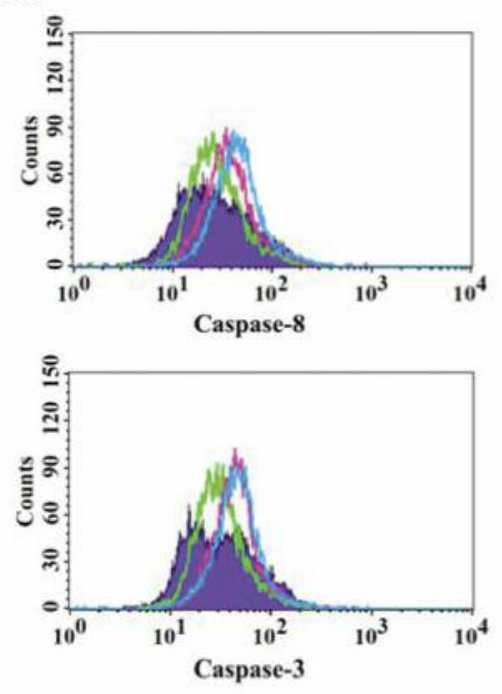
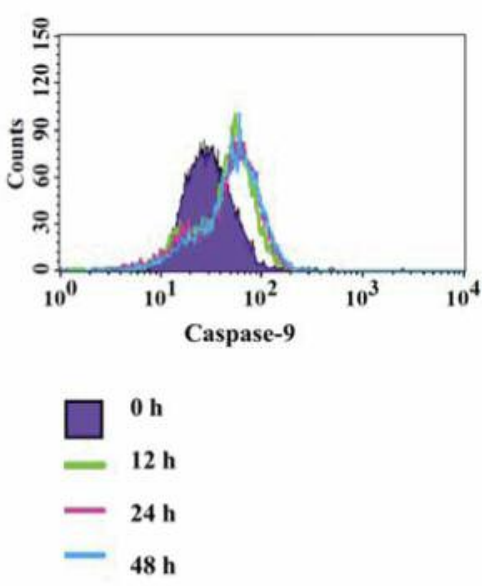

\section{B}

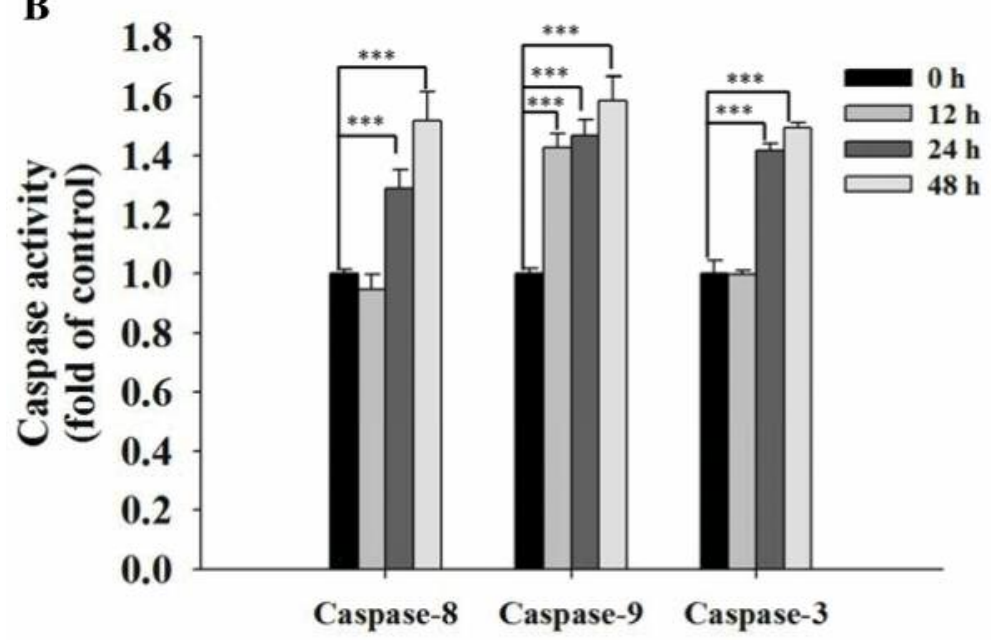

Figure 4. Ouabain affects caspase activity in U-2 OS cells. Cells were treated with $5 \mu M$ for $0,12,24$ and 48 h and intracellular activity caspase8, caspase-9, and caspase-3 was measured (A). Results (quantified) are presented in the graph (B). Asterisks denote the statistical significance of the experimental group compared to the corresponding control group $\left(* p<0.05, * * p<0.01, *^{* *} p<0.001\right)$.

SY5Y neuroblastoma cells were xenograft into immunedeficient mice (21). Cell-cycle arrests also have been recognized to be one of the mechanisms of anticancer drugs action $(22,23)$.

It is well-known that anticancer agent-induced apoptosis through ER stress involves production of ROS and $\mathrm{Ca}^{2+}$ release accompanied by mitochondrial dysfunction such as decreased $\Delta \Psi_{\mathrm{m}}$ levels $(24,25)$. Herein, we found that ouabain increased $\mathrm{Ca}^{2+}$ production, but decreased ROS production and the level of $\Delta \Psi_{\mathrm{m}}$ in U-2 OS cells (Figure 3). Other reports have shown ouabain to induce $\mathrm{Ca}^{2+}$ production (26) and ROS generation (27) that are involved in glioblastoma cell apoptosis. The contrary results might be due to the different cancer cell types, and further investigations are necessary. Though, the negative effect of ouabain on the level of $\Delta \Psi_{\mathrm{m}}$ in U-2 OS cells is in agreement with other reports on prostate cancer PC-3 cells (6).

Apoptosis pathway also can be divided into caspasedependent (28) and -independent (necroptosis) pathway (29). The caspase-dependent pathway is triggered by Fas and FasL interaction or death receptor for the activation of caspase- 8 and -3 to induce apoptosis (28). Otherwise, it can be triggered by dysfunction of mitochondria and subsequent release of AIF and Endo G to induce cell apoptosis without 
(A)

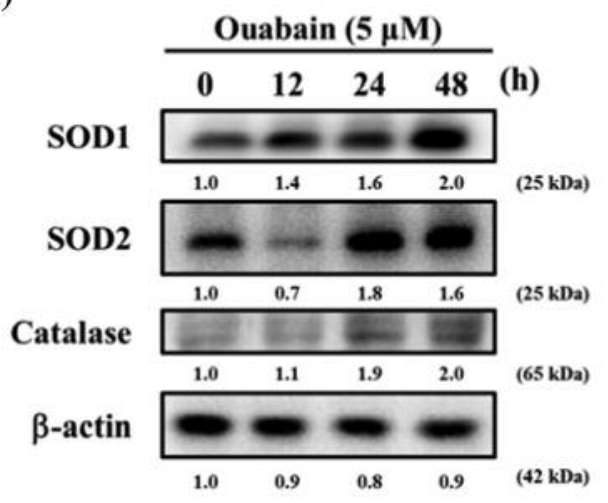

(C)

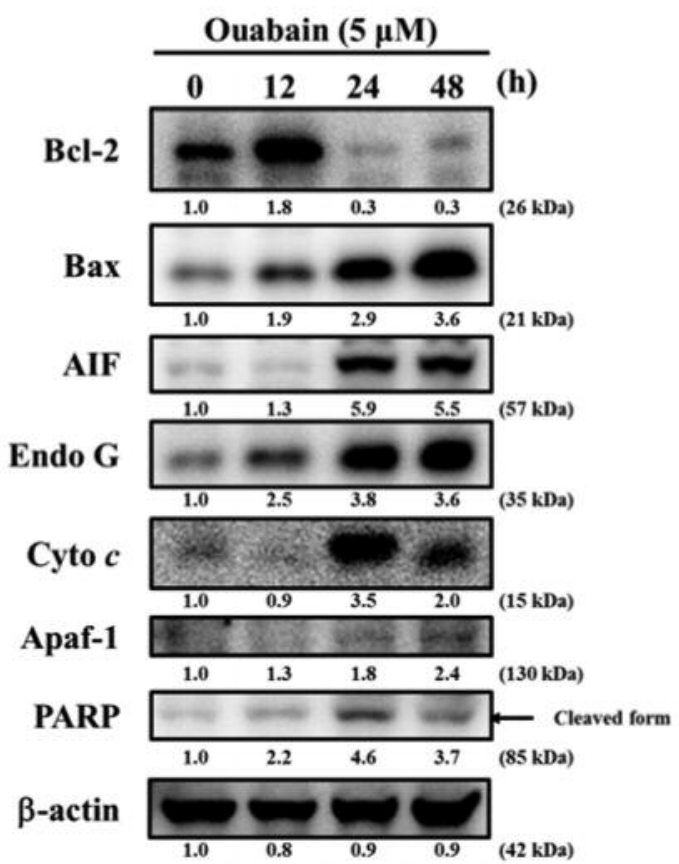

(B)

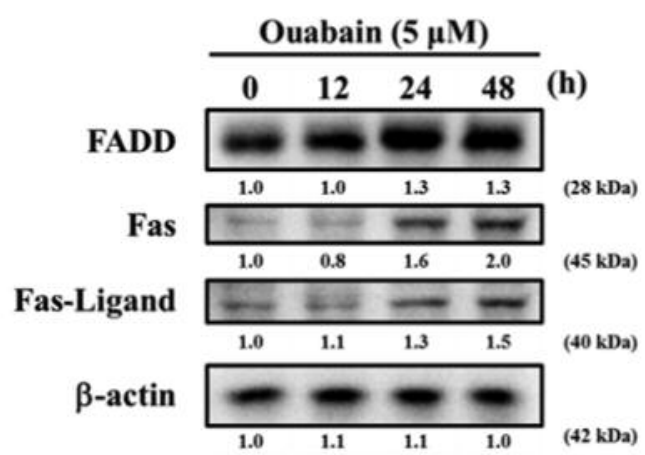

(D)

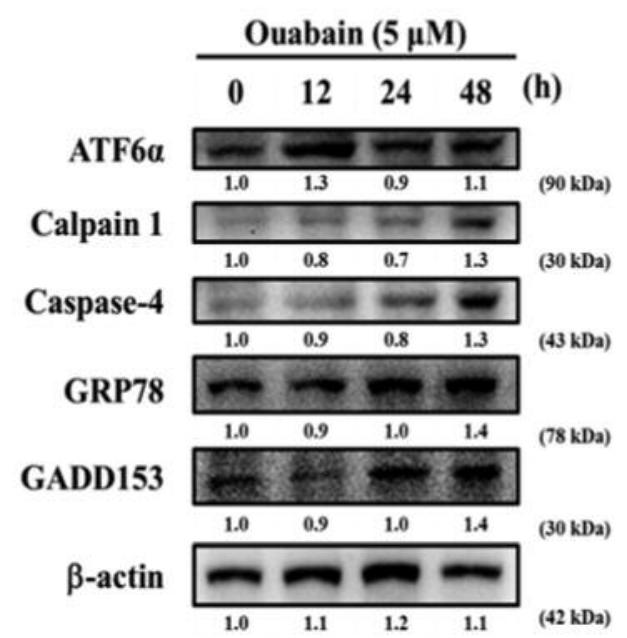

Figure 5. Ouabain affects the levels of apoptosis associated proteins in U-2 OS cells. The levels of SOD1, SOD2 and catalase (A); FADD, Fas, and Fas-ligand (B), Bcl-2, Bax, AIF, Endo G, cytochrome c, Apaf-1 and PARP (C), ATF6a, Calpain 1, Caspase-4, GRP78 and GADD153 (D) expressions were estimated by western blotting. Fold-changes values are displayed below each band.

caspase involvement (29). In the present study, we found that ouabain induced the activities of caspase- $8,-9$, and -3 in U-2 OS cells (Figure 4).

In order to further confirm ouabain-induced apoptotic cell death and whether it affects apoptosis-associated protein expression in U-2 OS cells, we examined protein expression in U-2 OS cells after exposed to $5 \mu \mathrm{M}$ of ouabain for various time periods. Results demonstrated that ouabain significantly inhibited the expression of anti-apoptotic protein Bcl-2 (Figure 5C) and increased pro-apoptotic protein Bax (Figure
5C) in U-2 OS cells. Previous evidence has shown that the ratio of the apoptosis-related proteins, $\mathrm{Bax} / \mathrm{Bcl}-2$, is associated with the level of $\Delta \Psi_{\mathrm{m}}(30,31)$. Herein, we clearly showed that ouabain increased the expression of cytochrome c, Afpa-1, PARP, AIF and Endo G (Figure 5C), indicating that ouabain-induced apoptosis was associated with mitochondrial dysfunction in U-2 OS cells. Furthermore, we also found that ouabain increased the expression of FADD, Fas, and FasL (Figure 5B) indicating that ouabain-induced cell apoptosis in U-2 OS cells might involve the activation of Fas and FasL. 
Thus, we may suggest that ouabain induced apoptosis of U-2 OS cells through caspase-dependent and also mitochondriadependent pathway.

In conclusion, ouabain induced $S-G_{2} / M$ phase cell-cycle arrest in U-2 OS cells, in vitro. Furthermore, ouabain induced apoptotic cell death with the involvement of caspase-dependent and -independent pathways, accompanied also by mitochondrial dysfunction. Thus, ouabain should be further examined in vivo, in order to justify its effectiveness in the prevention and treatment of osteosarcoma cancer.

\section{Conflicts of Interest}

The Authors do not have any conflicts of interest to disclose.

\section{Acknowledgements}

This study was supported by the grant 105-15 from Cheng Hsin General Hospital and SKH-8302-106-NDR-09 from Shin Kong Wu Ho-Su Memorial Hospital, Taipei, Taiwan; R.O.C.. Experiments and data analysis were performed in part through the use of the Medical Research Core Facilities Center, Office of Research \& Development at China medical University, Taichung, Taiwan, R.O.C.

\section{References}

1 Damron TA, Ward WG and Stewart A: Osteosarcoma, chondrosarcoma, and Ewing's sarcoma: National Cancer Data Base Report. Clin Orthop Relat Res 459: 40-47, 2007.

2 Ministry of Health and Welfare: 2016 statistics of causes of death, 2017.

3 Allison DC, Carney SC, Ahlmann ER, Hendifar A, Chawla S, Fedenko A, Angeles C and Menendez LR: A meta-analysis of osteosarcoma outcomes in the modern medical era. Sarcoma 2012: 704872, 2012.

4 Wachtel $\mathrm{M}$ and Schafer BW: Targets for cancer therapy in childhood sarcomas. Cancer Treat Rev 36: 318-327, 2010.

5 Holmboe L, Andersen AM, Morkrid L, Slordal L and Hall KS: High dose methotrexate chemotherapy: pharmacokinetics, folate and toxicity in osteosarcoma patients. Br J Clin Pharmacol 73: 106-114, 2012.

6 Huang YT, Chueh SC, Teng CM and Guh JH: Investigation of ouabain-induced anticancer effect in human androgenindependent prostate cancer PC-3 cells. Biochem Pharmacol 67: 727-733, 2004.

7 Schoner W: Endogenous cardiac glycosides, a new class of steroid hormones. Eur J Biochem 269: 2440-2448, 2002.

8 Chanvorachote $\mathrm{P}$ and Pongrakhananon V: Ouabain down-regulates Mcl-1 and sensitizes lung cancer cells to TRAIL-induced apoptosis. Am J Physiol Cell Physiol 304: C263-272, 2013.

9 Chen D, Song M, Mohamad O and Yu SP: Inhibition of $\mathrm{Na}^{+} / \mathrm{K}^{+-}$ ATPase induces hybrid cell death and enhanced sensitivity to chemotherapy in human glioblastoma cells. BMC Cancer 14: 716, 2014.

10 Pezzani R, Rubin B, Redaelli M, Radu C, Barollo S, Cicala MV, Salva M, Mian C, Mucignat-Caretta C, Simioni P, Iacobone M and Mantero F: The antiproliferative effects of ouabain and everolimus on adrenocortical tumor cells. Endocr J 61: 41-53, 2014.
11 Ozdemir A, Simay YD, Ibisoglu B, Yaren B, Bulbul D and Ark M: Cardiac glycoside-induced cell death and Rho/Rho kinase pathway: Implication of different regulation in cancer cell lines. Steroids 109: 29-43, 2016.

12 Liao CL, Lin JH, Lien JC, Hsu SC, Chueh FS, Yu CC, Wu PP, Huang YP, Lin JG and Chung JG: The crude extract of Corni Fructus inhibits the migration and invasion of U-2 OS human osteosarcoma cells through the inhibition of matrix metalloproteinase-2/-9 by MAPK signaling. Environ Toxicol 30: 53-63, 2015.

13 Huang WW, Chiu YJ, Fan MJ, Lu HF, Yeh HF, Li KH, Chen PY, Chung JG and Yang JS: Kaempferol induced apoptosis via endoplasmic reticulum stress and mitochondria-dependent pathway in human osteosarcoma U-2 OS cells. Mol Nutr Food Res 54: 1585-1595, 2010.

14 Ma YS, Weng SW, Lin MW, Lu CC, Chiang JH, Yang JS, Lai KC, Lin JP, Tang NY, Lin JG and Chung JG: Antitumor effects of emodin on LS1034 human colon cancer cells in vitro and in vivo: roles of apoptotic cell death and LS1034 tumor xenografts model. Food Chem Toxicol 50: 1271-1278, 2012.

15 Liu N, Li Y, Su S, Wang N, Wang H and Li J: Inhibition of cell migration by ouabain in the A549 human lung cancer cell line. Oncol Lett 6: 475-479, 2013.

16 Lee MR, Lin C, Lu CC, Kuo SC, Tsao JW, Juan YN, Chiu HY, Lee FY, Yang JS and Tsai FJ: YC-1 induces $\mathrm{G}_{0} / \mathrm{G}_{1}$ phase arrest and mitochondria-dependent apoptosis in cisplatin-resistant human oral cancer CAR cells. Biomedicine (Taipei) 7: 12, 2017.

17 Huang SH, Wu LW, Huang AC, Yu CC, Lien JC, Huang YP, Yang JS, Yang JH, Hsiao YP, Wood WG, Yu CS and Chung JG: Benzyl isothiocyanate (BITC) induces $\mathrm{G}_{2} / \mathrm{M}$ phase arrest and apoptosis in human melanoma A375.S2 cells through reactive oxygen species (ROS) and both mitochondria-dependent and death receptor-mediated multiple signaling pathways. J Agric Food Chem 60: 665-675, 2012.

18 Leung YM, Wong KL, Chen SW, Lu DY, Kuo CS, Chen YR, Chen YW and Cheng TH: Down-regulation of voltage-gated $\mathrm{Ca}^{2+}$ channels in $\mathrm{Ca}^{2+}$ store-depleted rat insulinoma RINm5F cells. BioMedicine 3: 130-139, 2013.

19 Chen LC, Hu LH and Yin MC: Alleviative effects from boswellic acid on acetaminophen-induced hepatic injury Corrected and republished from: Biomedicine (Taipei). 2016 Jun; 6(2): 9. doi: 10.7603/s40681-016-0009-1PMCID: PMC4864770. Biomedicine (Taipei) 7: 13, 2017.

20 Xu ZW, Wang FM, Gao MJ, Chen XY, Shan NN, Cheng SX, Mai X, Zala GH, Hu WL and Xu RC: Cardiotonic steroids attenuate ERK phosphorylation and generate cell cycle arrest to block human hepatoma cell growth. J Steroid Biochem Mol Biol 125: 181-191, 2011.

21 Hiyoshi H, Abdelhady S, Segerstrom L, Sveinbjornsson B, Nuriya M, Lundgren TK, Desfrere L, Miyakawa A, Yasui M, Kogner P, Johnsen JI, Andang M and Uhlen P: Quiescence and gammaH2AX in neuroblastoma are regulated by ouabain $/ \mathrm{Na}, \mathrm{K}-$ ATPase. Br J Cancer 106: 1807-1815, 2012.

22 Kuroda K, Fukuda T, Okumura K, Yoneyama H, Isogai H, Savage PB and Isogai E: Ceragenin CSA-13 induces cell cycle arrest and antiproliferative effects in wild-type and p53 null mutant HCT116 colon cancer cells. Anticancer Drugs 24: 826$834,2013$. 
23 Esmaeelian B, Benkendorff K, Johnston MR and Abbott CA: Purified brominated indole derivatives from Dicathais orbita induce apoptosis and cell cycle arrest in colorectal cancer cell lines. Mar Drugs 11: 3802-3822, 2013.

24 Kuo JH, Chu YL, Yang JS, Lin JP, Lai KC, Kuo HM, Hsia TC and Chung JG: Cantharidin induces apoptosis in human bladder cancer TSGH 8301 cells through mitochondria-dependent signal pathways. Int J Oncol 37: 1243-1250, 2010.

25 Kim SY, Kim SJ, Kim BJ, Rah SY, Chung SM, Im MJ and Kim UH: Doxorubicin-induced reactive oxygen species generation and intracellular $\mathrm{Ca}^{2+}$ increase are reciprocally modulated in rat cardiomyocytes. Exp Mol Med 38: 535-545, 2006.

26 Guild SJ, Ward ML, Cooper PJ, Hanley PJ and Loiselle DS: Extracellular $\mathrm{Ca}^{2+}$ is obligatory for ouabain-induced potentiation of cardiac basal energy expenditure. Clin Exp Pharmacol Physiol 30: 103-109, 2003.

27 Yan X, Liang F, Li D and Zheng J: Ouabain elicits human glioblastoma cells apoptosis by generating reactive oxygen species in ERK-p66SHC-dependent pathway. Mol Cell Biochem 398: 95-104, 2015.
28 Shah S, Gapor A and Sylvester PW: Role of caspase-8 activation in mediating vitamin E-induced apoptosis in murine mammary cancer cells. Nutr Cancer 45: 236-246, 2003.

29 Delavallee L, Cabon L, Galan-Malo P, Lorenzo HK and Susin SA: AIF-mediated caspase-independent necroptosis: a new chance for targeted therapeutics. IUBMB Life 63: 221-232, 2011.

30 Diep QN, Intengan HD and Schiffrin EL: Endothelin-1 attenuates omega3 fatty acid-induced apoptosis by inhibition of caspase 3. Hypertension 35: 287-291, 2000.

31 Yu CS, Huang AC, Lai KC, Huang YP, Lin MW, Yang JS and Chung JG: Diallyl trisulfide induces apoptosis in human primary colorectal cancer cells. Oncol Rep 28: 949-954, 2012.

Received September 22, 2017

Revised October 25, 2017

Accepted October 30, 2017 